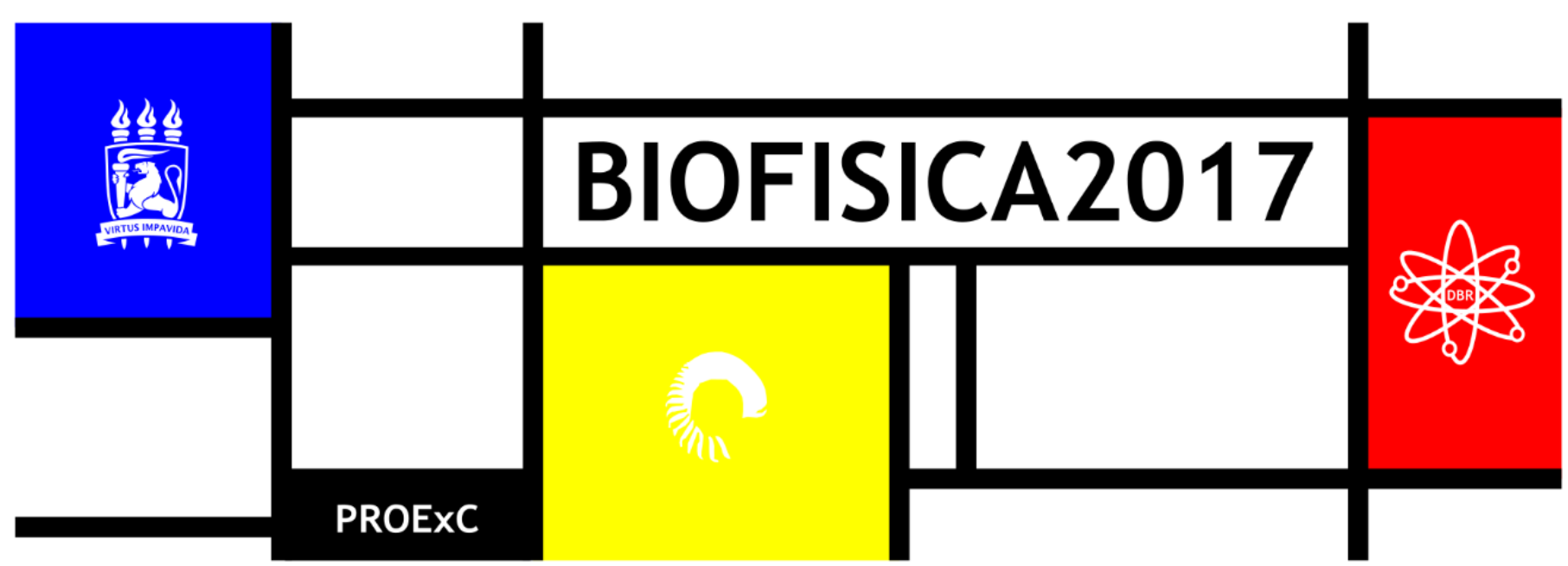

\title{
NANOPOROS PROTEICOS E ARTIFICIAIS NO SENSORIAMENTO ESTOCÁSTICO
}

\author{
Dijanah Cota Machado ${ }^{1, *}$
}

Departamento de Biofísica e Radiobiologia

*dijanahcm@yahoo.com.br

Nanoporos são poros em escala nanométrica com potenciais aplicações em diversos setores da atividade humana. Uma das aplicações é no sensoriamento estocástico de íons e moléculas diversas, inclusive no sequenciamento de DNA. 0 princípio básico de funcionamento do sensor estocástico baseia-se na inserção de um único nanoporo em um suporte isolante (por exemplo: bicamada lipídica, PDMS, entre outros) que divide uma câmara experimental em dois espaços preenchidos de solução eletrolítica. Quando um potencial elétrico é aplicado, um fluxo iônico é gerado através do nanoporo. As moléculas de um analito ao se difundirem para o interior do nanoporo provocam alterações transitórias no fluxo iônico, produzindo uma série temporal de flutuações na corrente iônica, que é característica a cada analito possibilitando sua identificação molecular. Os nanoporos podem ser artificiais (estado sólido, grafeno, entre outros) ou naturais. Os naturais ou biológicos são nanoporos proteicos formados por toxinas bacterianas como as de Bacillus anthracis, Aeromonas hydrophila, Mycobacterium smegmatis, Staphylococcus aureus. Dentre eles, o mais estudado e utilizado para fins de sensoriamento é o nanoporo proteico formado pela alfa-hemolisina (a-HL), exotoxina produzida pelo Staphylococcus aureus. 0 nanoporo de a-HL inserido em uma bicamada lipídica plana representa a classe dos sensores estocásticos que permitem a detecção de analitos ao nível de molécula unitária oferecendo, potencialmente, uma plataforma de sensoriamento altamente sensível, rápida e multifuncional. Visando aperfeiçoar a identificação do analito, a $\alpha-\mathrm{HL}$ pode ser usada na forma nativa, genética ou quimicamente modificada para a detecção de íons metálicos, proteínas, pequenas moléculas orgânicas, cianotoxinas, enantiômeros de fármacos, organofosforados, sequenciamento de DNA, entre outros. Outra estratégia para aumentar a sensibilidade da a-HL é por meio da alteração das condições físico-químicas da solução aquosa que banha o nanoporo-sensor. Estudos mostram que o aumento da concentração de $\mathrm{KCl}$ de 1 para $4 \mathrm{M}$ aumenta cerca de 100 vezes a sensibilidade e resolução do nanoporo de $\mathrm{\alpha}-\mathrm{HL}$ na detecção de moléculas poliméricas, além disso, o tipo do cátion ou ânion (íons da série de Hofmeister) constituintes da solução banhante também influenciam nestes parâmetros. As pesquisas com nanoporos vêm crescendo e se intensificando ao longo dos anos, visando o desenvolvimento de dispositivos sensores para a detecção, identificação, caracterização e quantificação de moléculas importantes nas áreas ambiental, industrial, militar, médica, biomédica, farmacêutica, agrícola, cosmética, forense e metrologia. 